E Q U I L I B R I U M

Volume 6 Issue 2, 2011

IS S N $1689-765 \mathrm{X}$

Jolanta Gadawska

University of Wroclaw, Poland

\title{
Effect of Provisions on the Valuation of a Company
}

\section{JEL Classification Codes: $G 3$}

Keywords: reserves/provisions, methods of valuating company, relations between reserves and the value of company

\begin{abstract}
Provisioning means the evaluation of future costs and losses, the estimation of future liabilities towards one's surroundings, an increase in equity, as well as the real value of assets.During asset valuation, the reserve balance may cause a reduction of the company's value - net assets. This could be a change of a few percentage points. Non-balance provisions cause a decrease in the value of assets, from which liabilities and reserves will be deducted. The value of the enterprise - through asset evaluation - will be lower by a few percentage points. However, it is supplementary capital (capital protection) which has the greatest importance in the methods a company uses in the valuation of assets. As research indicates, retained earnings and additional capital make up 30-59\% of owners equity. When using the multiplier method, reserves have a small indirect effect on the amount of dividends, net income decrease, etc. - due to the reducing of the financial result and taxes. The mixed method takes up an important position in the valuation of a company's goodwill. Therefore, the relevance of provisions in this valuation, will be lower than the during the valuation of assets. When valuating income reserves do not play a significant role. They are taken into consideration during the adjustment of the financial result, directing it towards cash flow, and for determining the financial outflows in the form of income tax. Provisions may also have a slight influence on the cost of the capital of the enterprise, i.e. a factor discounting cash flow.Provisions are not cash outflows and therefore, in the most popular income methods, they do not play a significant role. Reserves that are tax-deductible costs may affect the amount of tax burdens and thus indirectly affect the cash flow. The biggest and most direct effect of provisions on the valuation of a company can be observed in the asset methods as well as in the mixed methods. However, in the reserve multiplier methods affect the value of the multiplier element of a listed company and the value of the company measured the base element.
\end{abstract}




\section{Introduction}

The functioning of an enterprises in a market economy often forces the need for the valuation of the company. Traditional (the oldest) methods of valuation do not include the potential future cash flow possible to achieve from a particular undertaking (units) and are based on the valuation of assets/balance. While more recent methods take into account additional adjustment in the valuation of accounts. Using comparative evaluation, market conditions are taken into account, while during mixed evaluation - even the value of the company is respected (not disclosed in the balance sheet). What is impact do reserves/provisions on the valuation of a company? Provisions are construed not only as probable future obligations, but also as write-downs asset, impairment of assets as well as additional capital. The aim of this thesis is to verify the thesis that reserves, to some extent, have an effect on a company's valuation.

\section{The characteristics of reserves/provisions in Polish conditions}

Reserves are equivalent to retained growth funds maintained in the entity to cover anticipated costs or losses. The purpose of creating reserves is to show the correct amount of costs and outcomes of that period, in which the source lies, unspecified as to the amount or the financial decreasing. (Skrzywan 1971, p. 744). According to the Accounting Act reserves are created either on-going or on the day of the balance sheet for:

- certain or likely liabilities (Art. 35d), e.g. for retirement benefits,

- loss of business transactions in progress (Art. 35d),

- future liabilities arising from restructuring (Art. 35d),

- deferred income tax (Art. 37),

- covering insurance commitments (Art. 38),

- future period expenses - accrued expenses (Art. 39).

In units where the going concern assumption is not justified, there is an obligation to create reserves for anticipated additional costs and losses, due either to negligence or loss of ability to continue operations.

Provisions are reliably measured estimated values, in accordance with the principle of prudence. They use the degree of likelihood of incurring a liability or loss as well as the unit's past experience. Provisions appearing in liabilities are known as balance sheet liabilities, and in most cases are created under other operating costs, financing costs or extraordinary losses. They are resolved under other operating income, financial income and extraordinary income. Provisioning is also the maintenance of assets by taking specific actions aimed at increasing equity, or profit after tax reduction. Provisions are not only associated with 
Figure 1. Breakdown of reserves

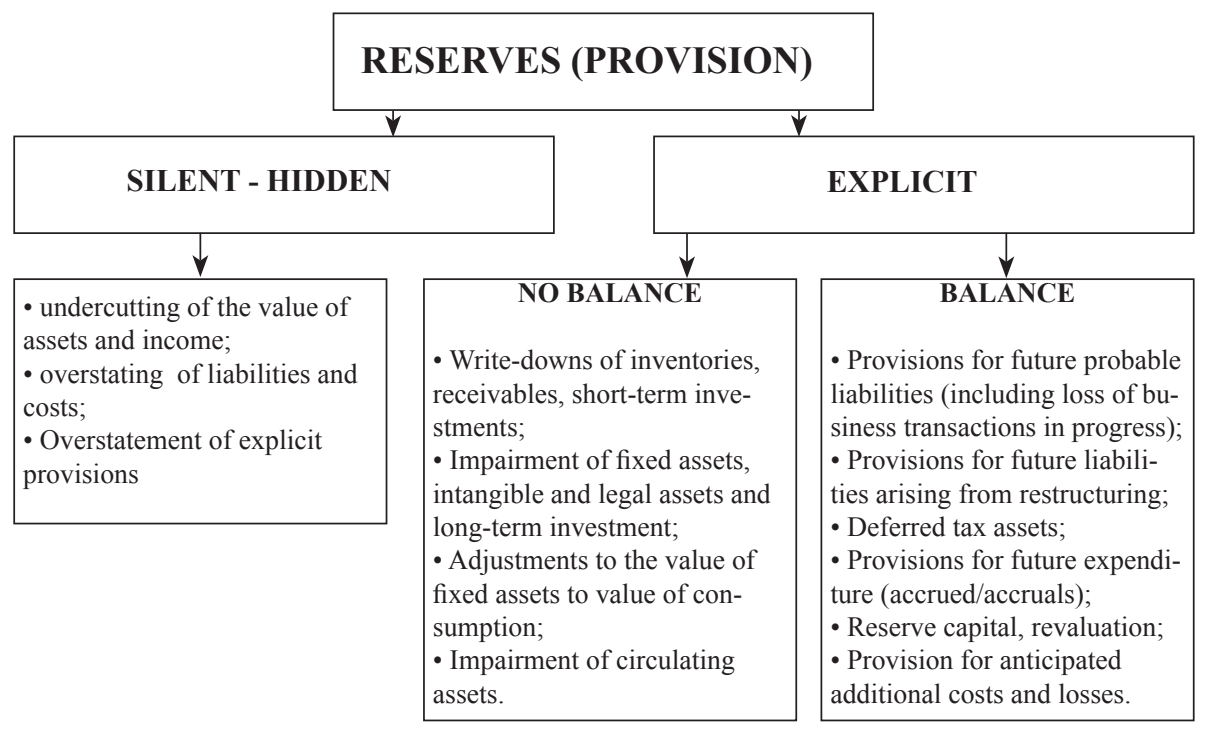

Source: own study based on the accounting regulations and literature on this subject, including Gmytrasiewicz 2007, p. 15.

liabilities, but also with individual assets and the need to adjust the value of assets (figure 1).

Fixed assets or financial updates consist (decrease) in particular of:

- fixed assets and intangible assets (Art. 28, Art. 31-33) - depreciation and impairment;

- fixed assets under construction (Art. 28, Art. 34a, b) - impairment;

- shares in other entities and other investments classified as current assets (Art. 28, Art. 35) - impairment;

- short-term investments (Art. 28, Art. 35) - loss of value;

- tangible assets (Art. 28, Art. 34) - loss of value;

- receivables and loans (Art. 28, Art. 35b, 35c) - impairment.

Information on write-downs, depreciation, permanent impairment and loss of values are in the supplementary data to the financial statements. The value of the assets is reduced by write-downs previously estimated and entered in the balance sheet. The size of such impairment depends on past due receivables, contractor status, etc.Resolved write-downs are recorded under revenue - other operational, financial and extraordinary income. Provisions for impairment of assets may apply to all assets except cash, and often result from comparing the book value of their current market value, with reality. Hidden provisions (quiet reserves) supplement explicit provisions (non-balance and balance) and are not 
disclosed in records and reporting. They define the valuation of assets as below their real value and demonstrate an excessive cost or obligation. They are a tool for "prudence" in the financial result and assets, without leaving traces of these procedures in the balance sheet.Thus, the creation of reserves is the estimation of expected costs and losses, estimates of future obligations to one's surroundings, increase in equity as well as getting the true value of the assets. Enterprises forming provisions must be keep in mind that the guiding the principles of accounting, not only show a need for their creation, but also warn against efforts at unwarranted creation of provisions.

The basic tasks of provisioning are:

- True value of assets, capital and earnings,

- Consideration of risks (if outflow of resources is probable),

- Counteracting the effects of risk (protection of the business unit).

However, the protective nature of reserves still is not as important as financial performance (its amount), which is to encourage investors, contractors and even lenders.

\section{Provisions in Polish business enterprises}

In order to verify the level of provisioning in Polish enterprises, the financial statements of the four largest listed companies have been used:

1) PKN Orlen Joint-Stock Company,

2) PGE Joint-Stock Company,

3) GNiG Joint-Stock Company,

4) KGHM Polska Miedź Joint-Stock Company.

The consolidated balance sheets analyzed in the above firms is from the years 2009 and 2010.

Table 1. Balance sheet provisions as total of the balance of a given enterprise

\begin{tabular}{|c|c|c|}
\hline Subject & $\mathbf{2 0 1 0}(\mathbf{\%})$ & $\mathbf{2 0 0 9}(\mathbf{\%})$ \\
\hline PKN Orlen S.A & 3.1 & 3.0 \\
\hline PGE S.A. & 6 & 5.9 \\
\hline PGNiG S.A. & 5.2 & 5.0 \\
\hline KGHM Polska Miedź & 2.6 & 3.8 \\
\hline
\end{tabular}

Source: the author's own work based on financial reports of the companies. 
Table 2. Reserve capital and revaluation capital and financial result in the total balance sheet of the enterprise

\begin{tabular}{|c|c|c|}
\hline Subject & $\mathbf{2 0 1 0}(\mathbf{\%})$ & $\mathbf{2 0 0 9}(\mathbf{\%})$ \\
\hline PKN Orlen S.A & $\mathbf{3 7}$ & $\mathbf{3 4 . 6}$ \\
\hline PGE S.A. & $\mathbf{3 5}$ & $\mathbf{2 5}$ \\
\hline PGNiG S.A. & $\mathbf{4 6}$ & $\mathbf{4 4}$ \\
\hline KGHM Polska Miedź & $\mathbf{5 9}$ & $\mathbf{5 6}$ \\
\hline
\end{tabular}

Source: the author's own work based on financial reports of the companies.

Table 3. Write downs of gross debtors in selected enterprises

\begin{tabular}{|c|c|c|}
\hline Subject & $\mathbf{2 0 1 0}(\mathbf{\%})$ & $\mathbf{2 0 0 9}(\mathbf{\%})$ \\
\hline PKN Orlen S.A & $\mathbf{8 . 4}$ & $\mathbf{9 . 2}$ \\
\hline PGE S.A. & 2.8 & 4.1 \\
\hline PGNiG S.A. & $\mathbf{2 1}$ & $\mathbf{2 3}$ \\
\hline KGHM Polska Miedź & 3.1 & 5.4 \\
\hline
\end{tabular}

Source: the author's own work based on financial reports of the companies.

Typical reserves (for future probable liabilities and losses in the course of business) were and are created by Polish entities at a minimum level. The balance sheet provisions (table 1) are a few percentage points of the total assets (from $2 \%-6 \%$ ). These provisions have little effect on the growth of liabilities future liabilities, an increase in costs or a reduction in the financial result. Taxes only reduce costs recognized for tax purposes. In some firms, write-offs of receivables have a rather large share of gross claims - up to $23 \%$. However, the value of assets changes by several percentage points. Taking into account depreciation and write-downs for impairment (all) have to reckon with the change of assets - reduced by several percent - to several dozen percent. Only tax expenses will be affected by taxes.Supplementary capital (retained earnings and reserve capital, revaluation capital) represents a significant value of liabilities in all the companies analyzed. Sometimes this capital is over $50 \%$ of all sources of financing. This means that the businesses want to protect themselves against possible net losses in the future.

\section{Business evaluation methods}

There are four groups of evaluation methods. These are the asset, comparative, mixed and revenue methods. The asset method is used for determining the val- 
ue of property based on the company's balance sheet. These include the book value method, adjusted book value method, liquidation and replacement value. According to the simplest asset method the value of the company is the value of equity contained in the balance sheet, i.e. net asset value.

Simplicity and ease made accounting in this method very popular in Poland between 1999-2003.

In the asset corrective method the books value of asset elements are replaced by market values. The adjusted asset method is a modification of asset methods.

Liquidation value is the minimum value (of the company) when it does not take into account the possibility of a going concern. The sum of the value obtained from the sale of assets, is to be deducted by any financial obligations that the company would incur in the event of its liquidation. Replacement value is the sum of investments, which must be made in order to create a company with the same criteria and characteristics, as the company being valuated.

The asset method does not include future development, conditions or internal company problems.

Comparative methods (multiplier indicative) are the most commonly used and simplest methods of business evaluation. They are based on the income statement, balance sheet and cash flow statement. This information is based on multiples of another, similar company, listed on the Stock Exchange (in the same sector and industry). The multiplier may be the market share price to earnings per share ratio $(\mathrm{P} / \mathrm{E})$, market price to book value ratio $(\mathrm{P} / \mathrm{BV})$, or market value company to sales ratio $(\mathrm{MC} / \mathrm{S})$. They may also take into account the value of the dividend. Multipliers are so constructed as show the ratio of market value to a specific company's economic variable. The value of a company is obtained by multiplying the ratios mentioned above by the base of the company being valuated. The base may be net profit, operating profit, sales value, book value or cash flow value for shareholders. This value can be determined by several variants, then the mathematical mean may be calculated, which determines the most average multiplier valuation.

Mixed methods include goodwill (the value of the company over the book value), which is visible in the books after the realization of a purchase - sales transaction. Goodwill relates to knowledge, experience, reputation, image, product brands, market position, level of customer service and customer loyalty. Mixed valuation is a static valuation of assets respecting the value that the company may generate in the future. Company value is the sum of the net asset value and the value of goodwill.

Discount methods show the income approach in the valuation of companies is characterized as relating to the value a company achieved with no revenue - cash flow, dividends or Economic Value Added. There are many options for determining the value of the company in terms of income. The company is worth as much as its income from this time today to infinity. 
The below are distinguished:

- The dividend method,

- The discounted cash flow method,

- The economic value added method.

In the dividend model it is assumed that dividends are the only cash flow being received by the investor. The value of the company will be the sum of its discounted dividends. A discount is the cost of owners equity.

Value of capital $=\sum_{t=1}^{t=\infty} \frac{E\left(D P S_{t}\right)}{\left(1+k_{e}\right)^{t}}$

where: $E(D P S t)$ - Expected dividend per share in $t$ period; $\mathrm{ke}$ - the cost of owners equity (expected rate of return on equity).

This method is applicable in mature companies paying a substantial portion of their profits as a dividend, with a stable capital structure, namely public utility companies or financial companies.

The dividend model (Gordon Model) assumes a steady increase in the dividend per share - from now to infinity.

Enterprise value $=\frac{D P S_{1}}{k_{e}-g}$

where: $D P S_{1}$ - dividend per share in the near term forecastke - the cost of equity (expected rate of return on equity) $g$ - the annual dividend growth rate.

The discounted cash flow model is a development of the dividend model. In fact, there are two types of discounted cash flows:

$-F C F E$ (free cash flow to equity), cash flow generated by equity, discounted at the cost of equity capital,

- FCFF (free cash flow to firm), cash flow achieved through equity and external capital, discounted at weighted average cost of capital (WACC)

$F C F E$ = Net income - capital expenditures + Depreciation - Change in working capital + Change in DebtFCFF $=$ Operating income minus theoretical tax - capital expenditure + Depreciation - Change in working capital + Change in balance of liabilities

$F C F F=$ Operating income reduced by theoretical tax - Capital expenditures + Depreciation - Change in working capital

$F C F F$ determines the discounting of cash flow at the cost of weighted average capital.

Value of company $=\sum_{t=1}^{t=\infty} \frac{F C F F_{t}}{(1+W A C C)^{t}}$ 
The value of equity $=$ Value of the company - Market value of interest liabilities (net)WACC is calculated as follows:

$$
W A C C=k d[D /(D+E)]+k e[E /(D+E)]
$$

where: $k_{d}$-after tax cost of debt, $k e$ - cost of equity, $D$ - the value of debt in financing the company, $E$ - the value of equity in the financing of the company. Cost of debt takes into consideration interest on borrowed capital and the tax shield. Financial costs of interest are tax expenses, they reduce taxes and thus reduce the effective cost of debt.

Cost of capital may also be a required rate of return on equity (return on investment). According to the Capital Asset Principle Model, the cost of capital depends on a risk-free rate and a premium on risk.

$$
k_{e}=r_{f}+\beta^{*}\left[E\left(r_{m}\right)-r_{f}\right]
$$

where: $k_{e}$ - cost of equity, $r_{f}$ risk-free rate, $E\left(r_{m}\right)$ - expected rate of return on market portfolio, $\beta$ - the systematic risk of equity, $\left[E\left(r_{m}\right)-r_{f}\right]-$ the risk premium.

Using the method of EVA is planned for subsequent years, the expected value of the EVA, and then they are discounted, then added to the value of equity and not interest-bearing debt, which the company had at the time of valuation. If an end valued the company is not known at the valuation, is estimated as - with regard to the rules force in the method of discounted cash flow - the residual value, that after discounting the value added to the above, give full estimated value of the entity using the EVA (Finance company 2003, pp. 273-274). The essence income methods is:

- linking value of company with net cash income in the future,

- forecasting cash flow discounted at a risk,

- flows from the residual - final value

- cash flow for 5 years with the amount from year 5 concerning the final value (Szczepankowski 2007, pp. 202-227).

The enterprise value is determined by the updated sum of expected financial income at the moment of valuation. The income methods are generally considered as the best way of valuating a company (Wyczarsk, Tu-van). 


\section{Relations of reserves/provisions on company valuation}

The size of reserves, as a natural consequence, affect the valuation of a company.

Maximizing reserve balance may cause:

- an increase in costs (remaining operational and financial),

- a reduction of the financial result,

- a reduction of tax burden (in cases where the reserves are tax- deductible costs),

- an increase in future liabilities.

The reserve balance sheet is mainly probable future liabilities. In determining the value of net assets, it is necessary to deduct not only liabilities from the total assets, but also the balance sheet reserves for future liabilities. Thus, during the evaluation of property, these balance reserves will reduce the company's value net assets. They may change them by a few percentage points.

Creating non-balance reserves will result in:

- an increase in costs,

- a reduction of the business unit's results,

- a reduction of tax,

- an increase in asset adjustments (reported in the notes),

- a reduction in value of either fixed or current assets in the balance sheet. Non-balance reserve will cause reduction of asset values from which the liabilities and reserves will be deducted. Enterprise value - at the asset valuation - will be reduced. If non-balance reserve assets are more than ten percent, then they will change the valuation of the company by several percentage points.

However, when using asset methods, supplementary capital is of the greatest importance in the valuation of the company. Research has indicated that retained earnings and additional capital form between $30-59 \%$ of equity. Thus, a large proportion of the value of a company, is determined by asset methods. An increase of capital means an increase in the value of the enterprise. Supplementary capital will have a significant and visible impact on a company's mixed valuation methods. When valuing assets, the adjusted reserves do not play as important a role, because in this case the value of the components of the subject must be brought to market value. An assessor may help in valuation. Liabilities and provisions for liabilities may be deducted in the balance sheet from the value of the asset (close to market prices).

The mixed method takes up an important position in the valuation of goodwill. Therefore the importance of reserves for this measure will be lower than the valuation of the assets.

However, in the multiplier method, provisions affect the value of the multiplier element in a listed company, e.g. in earnings per share in the case of $(\mathrm{P} / \mathrm{E})$, 
or the book value of the multiplier in (P/BV) and the measured value of the base element of the company - which may be net profit or operating profit. Small reserves (provisions)in a listed company may increase the multiplier and consequently increase the value of the enterprise evaluated. Small reserves in an enterprise subject to higher valuation will affect the value of the base element and thus increase the value of the company. Small reserves have the potential to pay higher dividends and thus, the valuation multiples based on dividends, will be high. It should be added that the market price of shares depends on how future investors perceive the enterprise. The future possibilities of the enterprise's development are important, as are the value of knowledge, intellect, brand, etc. However, the dividend depends on the size of the net financial result, which is accordingly reduced by the provision. This will reduce the value of the company.

When valuating revenue - reserves do not play a significant role. Earnings adjustments to the financial result leading to cash flow, and reduced taxes or cash outflow, are taken into account. They may affect the amount of dividends, and therefore the outflow of funds from financing activities, in the CF account.

The reserve balance and non-balance generate costs and will affect the cash flow of tax level. By creating reserves that are tax expenses, the tax will be reduced, therefore outflow of funds from business to the tax authority will also be lowered.

The creation of balance sheet reserves, and non-balance sheet reserves (impairment) will affect an increase in other operating costs or financial costs - in part, interest. This will reduce taxes and reduce the cash outflow (outflow). However, resolving reserves in terms of tax, will increase other operating or financial income - in part, interest. This will result in higher cash outflows in the form of tax. Thus, the income method, when creating income and solving typical balance sheet provisions and write-downs records, will have only an indirect impact on cash inflow and outflows. Therefore, the creation of provisions and revaluation of assets 'down' is not a cash outflow, while the release of provisions and writeoffs is not a financial impact, which is why the most popular reserve methods do not play a significant role (table 2 ).

Table 4. Ranges of impact of provisions for valuation of the company

\begin{tabular}{|c|c|c|c|c|}
\hline Reserves & $\begin{array}{c}\text { Capital } \\
\text { reserves }\end{array}$ & $\begin{array}{c}\text { Balance } \\
\text { reserves }\end{array}$ & $\begin{array}{c}\text { Non balance } \\
\text { reserves }\end{array}$ & $\begin{array}{c}\text { Quiet hidden } \\
\text { reserves }\end{array}$ \\
\hline Asset method & $\begin{array}{c}\text { Creating } \\
\text {-increase in value } \\
\text { of company }\end{array}$ & $\begin{array}{c}\text { Creating -reduce } \\
\text { value of company }\end{array}$ & $\begin{array}{c}\text { Creating -reduce } \\
\text { value of company }\end{array}$ & $\begin{array}{c}\text { Creating -reduce } \\
\text { value of company }\end{array}$ \\
\hline Correct method & $\begin{array}{c}\text { does not affect } \\
\text { value of the } \\
\text { company }\end{array}$ & $\begin{array}{c}\text { Creating -reduce } \\
\text { value of company }\end{array}$ & $\begin{array}{c}\text { Creating -reduce } \\
\text { value of company }\end{array}$ & $\begin{array}{c}\text { Creating -reduce } \\
\text { value of company }\end{array}$ \\
\hline
\end{tabular}


continued table 4

\begin{tabular}{|c|c|c|c|c|}
\hline $\begin{array}{c}\text { Multiplier } \\
\text { method - ratios } \\
\text { method }\end{array}$ & $\begin{array}{l}\text { no direct affect; } \\
\text { indirectly affects } \\
\text { the multipliers } \\
\text { and the base - } \\
\text { book value }\end{array}$ & $\begin{array}{l}\text { no direct affect; } \\
\text { indirectly affects } \\
\text { the multipliers } \\
\text { and the base } \\
\text { book value } \\
\text { net profit and } \\
\text { operating profit }\end{array}$ & $\begin{array}{l}\text { no affect; } \\
\text { indirectly on } \\
\text { the multipliers } \\
\text { and the base of } \\
\text { the book value } \\
\text { net profit, and } \\
\text { operating profit }\end{array}$ & $\begin{array}{l}\text { does not directly } \\
\text { affect, minimally } \\
\text { indirect }\end{array}$ \\
\hline $\begin{array}{c}\text { Income - } \\
\text { discount method }\end{array}$ & $\begin{array}{l}\text { no influence. } \\
\text { Indirectly affects } \\
\text { the cost of capital } \\
\text { and tax outflow }\end{array}$ & $\begin{array}{l}\text { indirectly affects } \\
\text { the cost of capital } \\
\text { and tax if there } \\
\text { are tax expenses }\end{array}$ & $\begin{array}{l}\text { indirectly affects } \\
\text { the cost of capital } \\
\text { and tax if write- } \\
\text { offs are tax } \\
\text { expenses }\end{array}$ & no influence \\
\hline Mixed method & $\begin{array}{l}\text { influences part of } \\
\text { the balance sheet } \\
\text { valuation, no } \\
\text { effect on value of } \\
\text { goodwill }\end{array}$ & $\begin{array}{c}\text { influences the } \\
\text { reduction of } \\
\text { the value of the } \\
\text { business in aspect } \\
\text { of the balance } \\
\text { sheet }\end{array}$ & $\begin{array}{c}\text { influences the } \\
\text { reduction of } \\
\text { the value of the } \\
\text { business in aspect } \\
\text { of the balance } \\
\text { sheet }\end{array}$ & $\begin{array}{l}\text { reduces the value } \\
\text { of the company } \\
\text { - in terms of } \\
\text { balance sheet }\end{array}$ \\
\hline
\end{tabular}

Source: authors study.

The direct impact of provisions for valuation of the company may, be observed in the asset and mixed methods (table 4).

It should be noted that when taking into account the value of net future cash flows - in the asset methods - not only depreciation, but provisions (which as a cost are not an expenses) must be added to operating profit. Financial surplus can be calculated as:

$$
C F=Z O(1-T)+A+R-\Delta K O-I
$$

where: $C F=$ financial surplus, $Z O=$ gain operational, $T=$ rate of income tax, $A=$ depreciation (expense), $R=$ reserve (as a cost), $\Delta K O=$ increase in working capital, $I=$ investment required.

Corporate literature often ignores the issue of balance sheet reserves, by indicating the models for calculating money from cash flow. 


\section{Conclusions}

In the asset methods, the impact of provisions on the valuation of the company is direct. In the case of balance sheet and non-balance sheet reserves (provisions) - it is a few percentage points. In the case of capital reserves it can even be in double-digits. It must be remembered that, while the reserve balance will reduce the value of the company, subsidiary capital will increase the value of equity.

In the adjusted value of assets method - reserves play a smaller role

and importance, because they take into account the market values of assets and some liabilities.

The reserve multiplier methods have a small indirect effect on the amount of dividends, net income, etc. - by reducing the financial results and tax.

In mixed methods, provision interact to a lesser extent than in the asset methods, by virtue of two areas comprising the value of the company. On the one hand they influence assets (decrease) and liabilities (increase), by only a few percentage. The greater extent, capital reserves affect the valuation. On the other hand they do not affect the value of the goodwill of the business being valuated.

In the income (discount) methods, cash flow is of key importance, and it has little in common with provisions. Unless, the provisions or write-offs are a cost of earnings gained, then the impact will be indirect through income tax (a reduction). There will also be an indirect impact on the dividend, or the single share price.

Provisions and write-downs have an impact on the balance sheet total. Therefore, they have a small indirect influence on equity weight in the calculation of average weighted cost of capital.

It is difficult to determine the impact of silent - hidden reserves/provisions not explicit - on the valuation of the company, because it is difficult for external users to determine their value, by investigating financial statements. Their impact on the valuation of the company will, however, be less than those of explicit provisions.

\section{Literature:}

Accounting Act, "Journal of Laws" No. 121 item. 591, uniform text. Coll. Laws of 2009, No. 152, poz.1223, died. Coll. Laws of 2009, No. 157, item. 1241).

Chluska J. (2001), Reserves in forecasting and financial planning in the enterprise: Materials Accounting Departments National Conference on the Evolution of the Polish accounting solutions on the background of the world, Micherda B., AE in Krakow, Krakow.

Dudycz T. (2010), Enterprise value management, ed. PWE, Warsaw.

Finance company. How to manage capital (2003), edited by Szczęsny, W., Beck, Warsaw Glynn J. J. (2003), Accounting for Managers, OWN, Warsaw.

Gmytrasiewicz M. (2007), Reserves Accounting, Difin, Warsaw. 
Jaki A. (2006), Valuation of Companies, Outbuilding of Economics, Cracow.

Jakubczyc J. (2008), Methods for Assessing Economic Projects, PWN, Warsaw.

Korenik D., Korenik S. (2008), Foundations of Finance, OWN, Warsaw.

Kufel M. (1992), Methods of Valuation of Companies, Publisher Park, Bielsko-Biala.

Methods for Business Valuation, and N. A. Wyczarska Tu-Van www.e-finanse.com/san/metody wyceny_przedsiebiorstw.ppt.

10th International Accounting Standards, IASC, London 2004, SK in Poland.

Niemczyk R. (2000), Reserves Accounting, ed. OPO, issue 157, Bydgoszcz.

Pomykalska B. Pomykalski P. (2007), Financial Analysis in a Company, PWE, Warsaw.

Sierpińska M., Jachna T. (2007), Financial Decision-making Methods - analysis of examples and cases, OWN, Warsaw.

Skowronek-Mielczrek A., Leszczynski, Z. (2008), Analysis of Operations and Business Development, PWE, Warsaw.

Skrzywan S. (1971), Little Encyclopedia of Accounting, PWE, Warsaw.

Szczepankowski P. (2007), Valuation and Value Based Management, OWN, Warsaw. 
